\title{
Managing occupational risks of greenhouse workers
}

\author{
Roman Chaplin, Svetlana Zhukova, Sergei Istomin, and Sergey Fomin* \\ Volga Interregional Branch of Research Institute of Labor of the Ministry of Labor of Russia, 410033 Saratov, Russia
}

\begin{abstract}
The article analyzes the results of a study on the implementation of an information system for managing occupational risks at a protected ground agro-industrial complex enterprise. By using the author's model of an automated information and reference system for assessing and controlling occupational risks, which contains the main elements of an occupational risk management system - a hazard identification block, an occupational risk analysis and assessment block, and an occupational risk management block, the company's management builds a strategy to increase the efficiency of the labor protection management system, expanding its operational and functional capabilities. The amount of occupational risk is calculated according to the author's method based on the information entered in the database of the automated information and reference system, according to such parameters as: health status, length of service, age, qualification of the employee, training in labor protection requirements and violation of labor protection requirements by a specific employee, category risk for identified industrial hazards. The introduction of an automated information and reference system for assessing occupational risks at the protected ground agroindustrial complex enterprise allowed not only to see possible risks, but also to accurately calculate their level, and to develop preventive measures to manage the identified risks.
\end{abstract}

\section{Introduction}

The work of agricultural workers has always been characterized by high physical activity, including performing many operations and carrying heavy loads manually, uncomfortable and forced postures, frequent tilting of the body, and long-term work on one's feet [1]. In addition to the above-mentioned characteristics, the work of agricultural workers of protected soil is aggravated by a complex of adverse factors related to the specifics of technological processes, which include microclimatic conditions (high or low air temperature, high humidity, intense insolation, low air mobility), air pollution of the working area with harmful chemicals, contamination of surfaces and air with bacterial microflora and helminth eggs.

Unfavorable working conditions are risk factors for the development of general and occupational diseases in greenhouse workers, which lead to temporary, and in some cases persistent disability. Among occupational diseases, workers in greenhouses demonstrate diseases of the musculoskeletal system and peripheral nervous system, diseases of the cardiovascular system, allergic diseases of the skin and respiratory system, reproductive health disorders, poisoning with toxic chemicals of acute and chronic forms [2, 3]. An assessment of occupational risk to the health from greenhouses with hygienic and biomedical indicators indicates the tension of regulatory systems and a decrease in adaptive capacity, which may be due to adverse working conditions [4].

The specifics of the technology for growing vegetables in greenhouses does not allow mechanization of labor, therefore more than $85 \%$ of the work is done manually, which is a key risk factor for injuries of greenhouse workers $[5,6]$.

The purpose of the study is development and implementation of an information and reference system for managing occupational risks at the protected ground agro-industrial complex enterprise.

\section{Materials and methods}

Investigations were made of the working conditions of protected soil vegetable growers of Sovkhoz-Vesna JSC, which included: analysis of the existing labor protection system of the enterprise; comprehensive analysis of the specific characteristics of injuries among workers, identifying the characteristics of groups of working personnel exposed to risk factors, establishing causal relationships; identification of hazards and compilation of a hazard catalog including information on who may be harmed and how.

An information and reference system for assessing occupational risks has been developed and an occupational risk management system has been proposed, including [7]: conducting an assessment of occupational risks based on an analysis of identified hazards and characteristics of employees of the enterprise; analysis of the system of preventive measures and measures to reduce the level of occupational risks; development of criteria for assessing the effectiveness of the current labor protection management system at Sovkhoz-Vesna JSC and directions for its improvement.

\footnotetext{
Corresponding author: fsd_58@mail.ru
} 


\section{Results and discussions}

The experimental site of the research was the protected soil enterprise of the agro-industrial complex of the Saratov region Sovkhoz-Vesna JSC, specializing in yearround growing of vegetables in protected soil, as well as oyster mushrooms on a substrate made of sunflower husk. The study was conducted in the period 2013-2018. The headcount is 651 people.

The management of labor protection at the enterprise is carried out by the Director General through compliance with the state normative requirements of labour protection taking into account the specifics of its activities, achievements of modern science and best practices, commitments and international, intergovernmental and national standards, guidelines and recommendations of the International labour organization on $\mathrm{OSH}$ and production safety. Responsibilities for compliance with labor protection requirements are delegated to the company's labor protection specialist. It should be noted that all instructions and training on labor protection at the enterprise are carried out in a timely manner.

During the research period, the company developed and implemented a labor protection management system based on the assessment and management of occupational risks.

During the study period, 28 accidents occurred in Sovkhoz-Vesna JSC, the main reasons for which were design flaws and carelessness.

Analysis of the nature of injuries showed that $43 \%$ of the total number of injuries are caused by greenhouse workers falling from technological trolleys, $29 \%$ - falls as a result of tripping and slipping, $11 \%$ - injuries to locksmiths when glazing greenhouses (Figure 1).

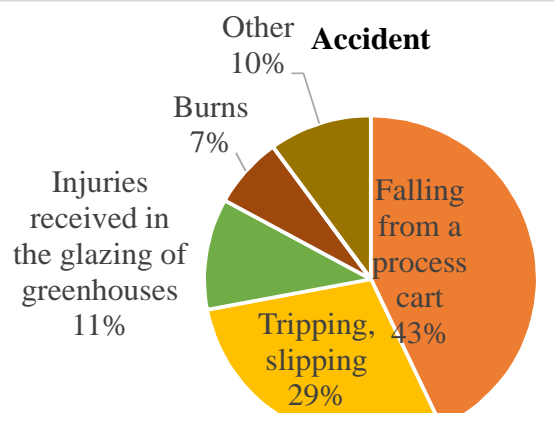

Fig. 1. Causes of accidents in Sovkhoz-Vesna JSC for the period 2013-2018.

The most susceptible to injuries were vegetable growers (17 cases, 61\%), locksmiths (5 cases, 18\%) and drivers ( 3 cases, $11 \%$ ).

The analysis of accidents in the context of professions and age of employees showed that the risk group is vegetable growers older than 45 years.

The causes of most accidents that occurred with vegetable growers were technological imperfection of equipment and carelessness. The most characteristic is injury to the limbs of employees, head and body contusions.
The cause of accidents that occurred with locksmiths, most often were falls from stairs when glazing greenhouses - three cases out of five. One case is related to injuries due to loading and unloading operations, and another accident resulted in a pipe falling on the employee's head.

Analysis of the gender and age staff of the enterprise revealed that most of the employees are women $-62 \%$ (401 persons), mainly vegetable growers and $43 \%$ of all employees (281 persons), technicians, storekeepers, etc. The presence of a large number of employees over the age of 45 was taken into account (Figure 2).

The age of the employees of Sovkhoz-Vesna JSC

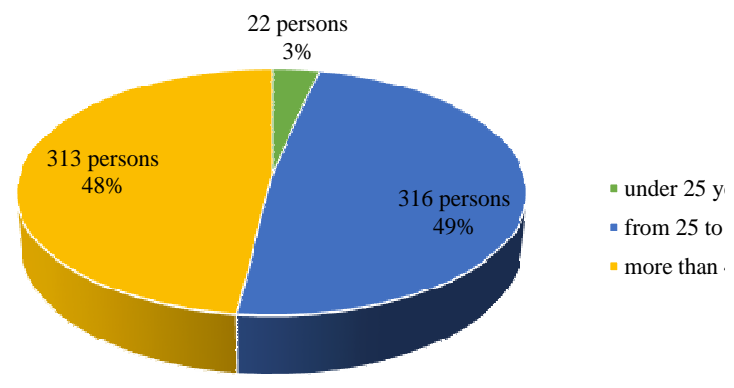

Fig. 2. Age structure of employees of Sovkhoz-Vesna JSC.

It should be noted that about a third of the company's employees have a continuous work experience of more than 15 years (Figure 3 ).

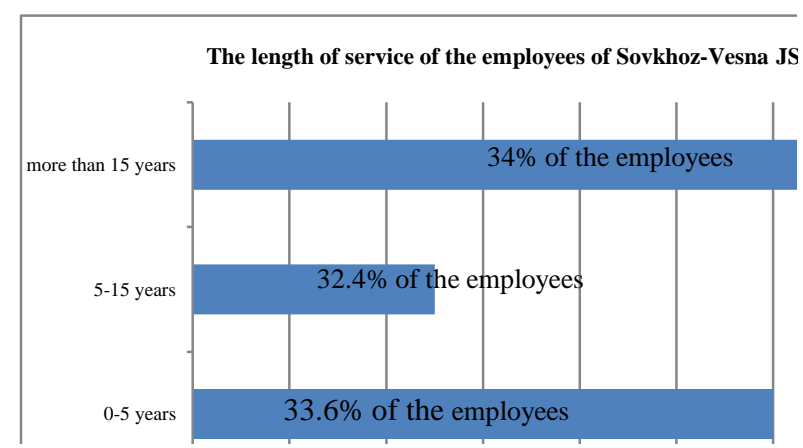

Fig. 3. The length of service of the employees of SovkhozVesna JSC.

Occupational risks management is an integral part of enterprise management, which requires the use of mathematical models, methods and information technologies. Therefore, it is impossible to build an effective professional risk management system integrated into the enterprise management process without using an appropriate information system.

The proposed automated information and reference system contains a minimum sufficient number of factors that affect the level of professional risk and does not require the involvement of additional specialists [8,9]. The structure of the professional risk management information system consists of:

- hazard identification block, including:

- list of jobs;

- list of hazards, harmful and dangerous factors; 
- values of maximum permissible concentrations (MPC) and maximum permissible levels (MPL) of harmful and dangerous substances, as well as standards of severity and intensity of work, criteria for injury, standards for providing personal protective equipment (PPE);

- statistics on injuries and occupational diseases;

- occupational risk analysis and assessment block, which includes a methodology for assessing professional risks;

- occupational risk management block, which includes:

- methods of occupational risk management;

- forms of accounting for occupational risks in the enterprise's labor protection management system;

- directions of preventive work to reduce the level of occupational risks.

In order to optimize the identification of hazards of injuries in the workplace, the complex of production areas of the enterprise was divided into sections, for each of which a catalog of hazards was compiled, including information about who may be injured and how. During the implementation of the automated information and reference system for assessing and controlling occupational risks, a list of identified hazards was formed (Figure 4).

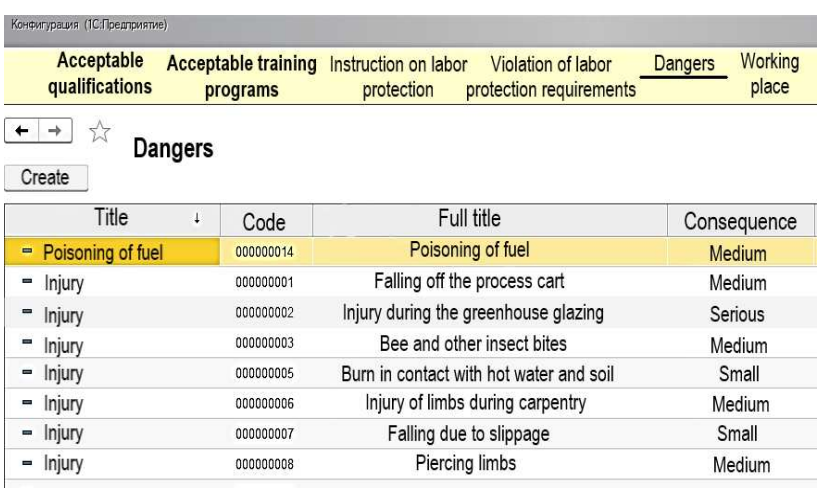

Fig. 4. Screenshot of the automated information and reference system for assessing and controlling occupational risks.

One of the advantages of the proposed program is the ability to display a catalog of enterprise hazards as a separate document [8]. An example of a catalog of identified hazards is presented in Table 1 .

The assessment of occupational risks of employees was carried out on the basis of collected data on employees, workplaces and working conditions automatically, after entering the data into the automated information system for assessing occupational risks.

Table 1. Example of a catalog of identified hazards

\begin{tabular}{|c|c|c|c|c|c|c|}
\hline Area & Danger & $\begin{array}{l}\text { Who might get } \\
\text { hurt }\end{array}$ & $\begin{array}{c}\text { Conditions of } \\
\text { danger(Normal } \\
\text { operation (N) } \\
\text { and emergency } \\
\text { situations (A)) } \\
\end{array}$ & $\begin{array}{l}\text { Measures to } \\
\text { eliminate the } \\
\text { danger }\end{array}$ & $\begin{array}{c}\text { Responsible } \\
\text { person }\end{array}$ & $\begin{array}{c}\text { Term of } \\
\text { execution }\end{array}$ \\
\hline $\begin{array}{l}\text { Greenhouse } \\
\text { block no.2 }\end{array}$ & $\begin{array}{l}\text { Injuries caused } \\
\text { by falling from } \\
\text { the process cart }\end{array}$ & $\begin{array}{l}\text { Greenhouse workers } \\
\text { (vegetable growers) }\end{array}$ & $\mathrm{N}$ & $\begin{array}{l}\text { Replace process } \\
\text { cart with safe ones }\end{array}$ & Ivanov A.A. & $\begin{array}{l}\text { December } \\
2016\end{array}$ \\
\hline $\begin{array}{l}\text { Greenhouse } \\
\text { blockno.3 }\end{array}$ & $\begin{array}{l}\text { Injuries due to } \\
\text { tripping, falling }\end{array}$ & $\begin{array}{l}\text { Greenhouse workers } \\
\text { (vegetable growers, } \\
\text { locksmiths- } \\
\text { repairmen, } \\
\text { agronomists) }\end{array}$ & $\mathrm{N}$ & $\begin{array}{l}\text { 1. Install } \\
\text { protective fences } \\
\text { along the beds. } \\
\text { 2. Monitor the } \\
\text { integrity of the } \\
\text { greenhouse floor } \\
\text { covering }\end{array}$ & $\begin{array}{l}\text { Petrov V.V. } \\
\text { Sidorov S.S. }\end{array}$ & $\begin{array}{l}\text { October } \\
2016 \\
\text { Constantly }\end{array}$ \\
\hline $\begin{array}{l}\text { Greenhouse } \\
\text { block no.1, } \\
2,3,4\end{array}$ & $\begin{array}{l}\text { Injuries caused } \\
\text { by working with } \\
\text { glass: cuts, } \\
\text { falling from a } \\
\text { height }\end{array}$ & $\begin{array}{l}\text { Locksmiths- } \\
\text { repairmen }\end{array}$ & $\mathrm{N}$ & $\begin{array}{l}\text { 1. Monitor the } \\
\text { use of PPE by } \\
\text { employees. } \\
\text { 2. Replacing the } \\
\text { glass with } \\
\text { polycarbonate. }\end{array}$ & $\begin{array}{l}\text { Kozlov P.T. } \\
\text { Manager, } \\
\text { software } \\
\text { engineer }\end{array}$ & Constantly \\
\hline
\end{tabular}

According to the method of the authors the calculation of occupational risk is made using the claimed system for indicators of working conditions in the organization according to the following formula:

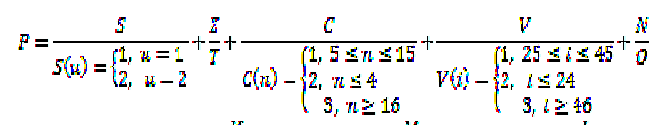

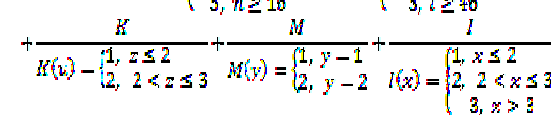

The risk for a production environment, where: $S$ is working conditions in the organization based on the materials of a special assessment of working conditions, $S(u)$ are acceptable values.
Acceptable values will be class 1 and 2 of working conditions in accordance with the results of a special assessment of working conditions.

Risk based on medical indicators, where: $Z$ is the presence or absence of occupational diseases in a particular employee; $T$ is the presence or absence of contraindications to performing certain types of work for a particular employee.

Risk by length of service, age, qualification, where: $C$ is length of service of a particular employee; $C(n)$ is length of service coefficient. The optimal work experience is $5-15$ years, anything less or more is an increased risk; $V$ is the age of the specific employee; $V(i)$ is a coefficient of optimal age. The optimal age is $25-45$ 
years; $K$ is qualification indicators of a specific employee; $K(z)$ is acceptable qualifications for working in this workplace. Qualification indicators can be either valid (with a coefficient equal to 1), or invalid (with a coefficient equal to 2 ).

Risk on the indicator of passing training in labor protection requirements, including marks on passing instructions and periodic verification of knowledge of the enterprise's personnel, cases of violation of labor protection requirements by employees of the enterprise, where: $M$ are actual indicators of completion of training in occupational safety requirements by a specific employee, including marks of passing instructions, information about periodic knowledge verification; $M(y)$ are acceptable training indicators that correspond to the individual training schedule, briefing, and testing of the employee's knowledge. These indicators can be either valid (with a coefficient equal to 1), or invalid (with a coefficient equal to 2).

$N$ is the number of violations of labor protection requirements for a particular employee; $O$ is the number of violations of labor protection requirements in total for the organization.

Risk for identified industrial hazards, where: $I$ is a risk category for identified occupational hazards in the workplace; $I(x)$ is an acceptable risk category for identified industrial hazards. Risk categories 1 and 2 are acceptable.

Correction coefficients may vary depending on the workplace at the agribusiness enterprise and are selected individually at the time of starting the system simultaneously with the filling of databases. If the situation changes, the coefficients may change.

\begin{tabular}{|c|c|c|c|}
\hline $\begin{array}{l}\text { Acceptable } \\
\text { qualifications }\end{array}$ & $\begin{array}{l}\text { Acceptable training Instruction on labor } \\
\text { programs protection }\end{array}$ & $\begin{array}{l}\text { Violation of labor } \\
\text { protection requirements }\end{array}$ & $\begin{array}{c}\text { Dangers Working } \\
\text { place }\end{array}$ \\
\hline
\end{tabular}

\begin{tabular}{|c|c|c|c|}
\hline Settlement date 22.02 .2018 & 田 & Occupational risk & $\underline{\mathbf{3 . 8 6 7}}$ \\
\hline Employee & \multicolumn{3}{|c|}{ Sazonov, S. F. } \\
\hline Working conditions & \multicolumn{3}{|c|}{2 - Acceptable working conditions } \\
\hline Contraindications & \multicolumn{3}{|l|}{ No } \\
\hline $\begin{array}{l}\text { Length of } \\
\text { service }\end{array}$ & 41 & $\begin{array}{l}\text { Coefficient of work } \\
\text { experience }\end{array}$ & 3 \\
\hline Age & 61 & $\begin{array}{l}\text { Coefficient of optimal } \\
\text { age }\end{array}$ & 3 \\
\hline
\end{tabular}

- The risk for an employee Dyakov S.A. is 5.292

- The risk for an employee Nikonina N.V. is 4.625

Fig. 5. Screenshot of the automated information and reference system for assessing and controlling occupational risks.

Table 2. Risk indicators depending on the degree of hazard of the work

\begin{tabular}{|c|c|c|c|}
\hline $\begin{array}{c}\text { Level of } \\
\text { occupational risk }\end{array}$ & Low & Medium & High \\
\hline $\begin{array}{c}\text { Indicator of the level } \\
\text { of occupational risk }\end{array}$ & $\begin{array}{c}5.000- \\
6.000\end{array}$ & $\begin{array}{c}4.000- \\
5.000\end{array}$ & $\begin{array}{c}3.000- \\
4.000\end{array}$ \\
\hline
\end{tabular}

The level of occupational risk can range from 3.000 to 6.000 units, and the higher the employee's occupational risk, the lower the indicator of the level of occupational risk. For example, an employee with the most unfavorable data from the point of view of labor protection (who has violations of labor discipline, occupational diseases, did not pass timely training on labor protection, with minimal indicators of length of service and age, working in dangerous working conditions, etc.), the risk level indicator will tend to 3.000 , and on the contrary, an "ideal" employee working in ideal working conditions, the risk level indicator will tend to 6.000 (Figure 5).

Analysis of the data set on the level of occupational risk of employees of Sovkhoz-Vesna JSC allowed us to rank the risk indicators depending on the degree of danger of work (Table 2).

Information about the level of occupational risks of employees allowed us to build a risk management system at the enterprise, develop measures to reduce occupational risks and determine the priority of activities within the occupational risk management unit of the information and reference system.

In the course of the study, the company identified potentially dangerous factors from the point of view of employee injuries:

- Imperfection of technological cart.

- The need for work on glazing.

- A large number of employees over 45 years of age.

The study of gender and age characteristics allowed us to get a picture of the latent danger of injury to employees for two reasons:

- first of all, the longer an employee works in one place, the more often they neglect security requirements, since they rely on their extensive life experience;

- secondly, with age, physical strength, endurance, flexibility of the body decreases, so the probability of injury due to a fall increases.

In addition, the study assessed the individual occupational risk of each employee and thus identified a group of employees exposed to potential risks of injury in the workplace, which allowed us to develop organizational and engineering methods to reduce the individual occupational risks of employees, and, accordingly, the enterprise as a whole.

The following measures were put forward as priorities for managing occupational risks:

- engineering and technical:

- replacement of old technological trolleys with modern ones;

- replacement of the previous design of glass openings with the author's method and device for ensuring safety during maintenance and repair of glass openings of sloping roofs of greenhouses [9];

- organizational:

- work with employees (informing about hazards, discussing safe methods of work in greenhouses, observing the work and rest regime, etc.);

- introduction of a mentoring system, attracting young employees. 
The main objectives of organizational measures are to increase the awareness of risk on the part of each employee, to form an understanding of methods to ensure safe human behavior.

The criteria for effective implementation of the information system for assessing professional risks in Sovkhoz-Vesna JSC are:

- reducing the risk of accidents and accidents at the enterprise;

- minimization of the number and amount of compensation and penalty payments imposed by supervisory authorities;

- reduction of non-production losses and unexpected expenses;

- increased security;

- increased productivity;

- satisfaction of the employees;

- cost efficiency.

\section{Conclusion}

The introduction of an automated information and reference system for assessing occupational risks allowed us to develop a set of preventive measures to reduce the level of occupational risks in Sovkhoz-Vesna JSC, cover all areas of possible occurrence of occupational risks, while highlighting the most priority measures that can have a preventive effect on dangerous areas. The developed proposals form an effective strategy for risk management and injury prevention.

\section{References}

1. V.S. Shkrabak, N.I. Jabborov, E.V. Piadichev, Proceedings of the Saint Petersburg State Agrarian University, 38, 317-324 (2015)

2. A.D. Trubetskov, A.G. Migacheva, A.M. Starshov, International journal of applied and fundamental research, 4-2, 383-385 (2016). Retrieved from: https://applied-research.ru/ru/article/view?id=8978

3. A. Rosano, V. Gemelli, C. Giovannelli, G. Paciotti, A. Sabatucci, A. Spagnolo, Med Lav., 100(6), 448454 (2009). Retrieved from: https://pubmed.ncbi. nlm.nih.gov/20359137/

4. A.G. Migacheva, V.F. Spirin, Occupational medicine and industrial ecology, 9, 28-32 (2017)

5. V.S. Shkrabak, P.S. Orlov, L.A. Goldobina, R.V. Shkrabak, E.S. Popova, Agrarian scientific journal, 5, 58-64 (2015)

6. S.V. Yanchiy, N.D. Degtyarev, Young scientist, 4, 95-100 (2017)

7. N.P. Kryukov, V.S. Shkrabak, S.V. Istomin, R.I. Chaplin, R.V. Shkrabak, S.A. Zhukova, Patent for the invention "Automated information and reference system for assessment and management of professional risks at agricultural enterprises", No. 22638640 (December 14, 2017)

8. S.P. Levashov, Occupational risk: methodology of monitoring and analysis: monograph (2015)

9. S.V. Istomin, R.I. Chaplin, S.A. Zhukova, R.V. Shkrabak, A.V. Shkrabak, V.S. Shkrabak, Patent for invention: "Method and device for ensuring safety during maintenance and repair of glass openings of sloping roofs of greenhouses", No. 2653877 (May 15, 2018) 